\title{
A polyclinally folded biotite grain in micro-scale
}
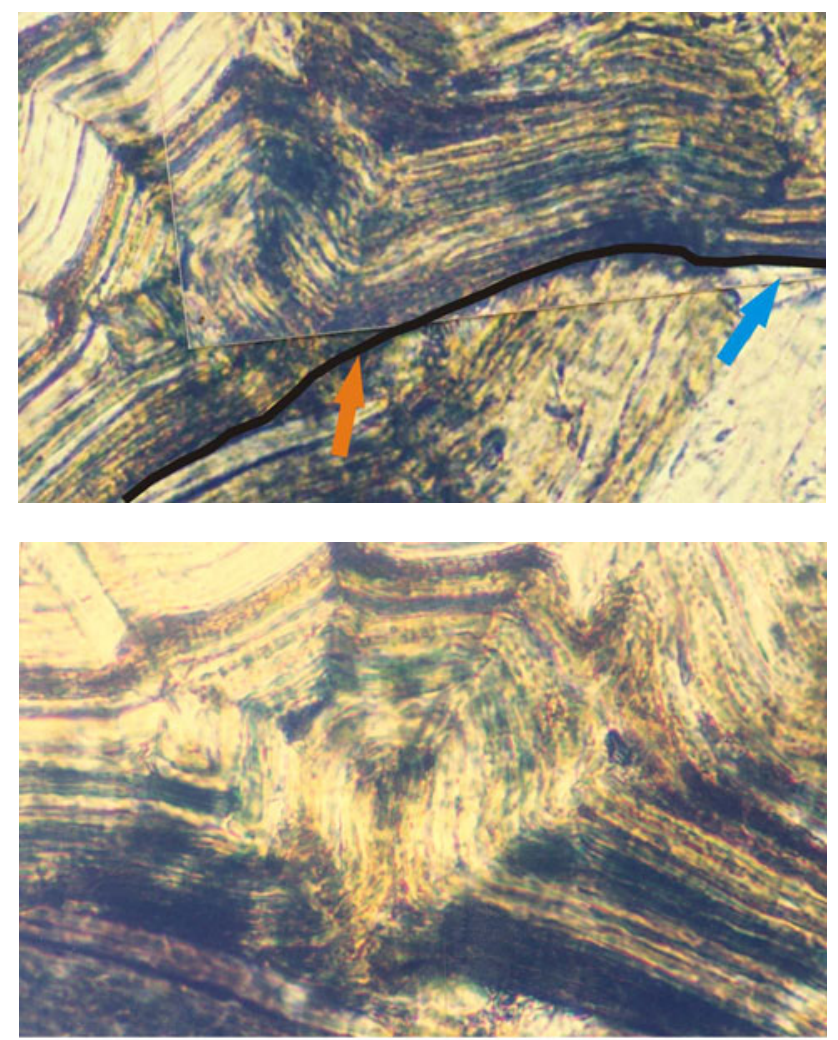

Supporting figure

A kinked polyclinally folded biotite grain with gently curved limbs of approximately the same thickness (parallel fold geometry). Its four axial traces converge at the core at a box fold (similar to one of the oldest accounts of such folds from field such as Buxtorf (1916). The supporting figure zooms the axial part of the fold (also compare with fig. 16.18d of Fossen 2010). Since the underlying mica grain is not folded, whereas the overlying biotite is, it can also be called a detachment- or a décollement fold (see Fossen 2010; also see fig. 7-81 of Ramsay 1967). Since the supporting photo was taken at an extremely high magnification, additional yellow light was made incident on the thin-section to gain clarity (but at the cost of yellowing). Kinking of biotite grains is a common micro-structural phenomenon and has been attributed to bend-gliding of crystals (Hills
1965) or due to dislocation gliding (Spry 1969). Notice that Mukherjee (2011a) recently reported a duplex structure defined by mica grains in micro-scale (also Mukherjee 2007, 2010a, b, 2011b; Mukherjee and Koyi 2010a, b). Rock: sandstone; photo in plane polarized light, photo length: $0.25 \mathrm{~mm}$. Location: Mohand, Uttarakhand, India.

Acknowledgments Baidehi Mukherjee (Schlumberger Oilfield UK Plc Limited) supplied the thin-section. Reviewed by Holger Stünitz (Universitetet i Troms $\varnothing$ ). Editorial handling by Claudio Rosenberg (Institut für Geologische Wissenschaften) and Wolf-Christian Dullo (IFM-GEOMAR).

\section{References}

Buxtorf A (1916) Prognosen und Befunde beim Hauensteinbasis- und Grenchenbergtunnel und die Bedeutung der letzteren fur die Geologie des Juragebirges. Verh Naturforsch Ges Basel 27:185-254

Fossen H (2010) Structural geology. Cambridge University Press, Cambridge, p 322

Hills ES (1965) Elements of structural geology. Asia Publishing House, Bombay, p 117

Mukherjee S (2007) Geodynamics, deformation and mathematical analysis of metamorphic belts of the NW Himalaya. Unpublished $\mathrm{Ph} . \mathrm{D}$. thesis, Indian Institute of Technology, Roorkee, pp 1-267

Mukherjee S (2010a) Structures at meso and micro-scales in the Sutlej section of the Higher Himalayan Shear Zone in Himalaya. e-Terra 7:1-27

Mukherjee S (2010b) Microstructures of the Zanskar Shear Zone. Earth Sci India 3(I):9-27

Mukherjee S (2011a) A micro-duplex. Int J Earth Sci (in press)

Mukherjee S (2011b) Tectonic implications and morphology of trapezoidal mica grains from the Sutlej section of the Higher Himalayan Shear Zone, Indian Himalaya. Int J Earth Sci (submitted)

Mukherjee S, Koyi HA (2010a) Higher Himalayan Shear Zone, Sutlej section- structural geology and extrusion mechanism by various combinations of simple shear, pure shear and channel flow in shifting modes. Int J Earth Sci 99:1267-1303

Mukherjee S, Koyi HA (2010b) Higher Himalayan Shear Zone, Zanskar Indian Himalaya-microstructural studies and extrusion mechanism by a combination of simple shear and channel flow. Int J Earth Sci 99:1083-1110

Ramsay JG (1967) Folding and fracturing of rocks. McGraw Hill Book Company, New York, p 416

Spry A (1969) Metamorphic textures. Pergamon, Oxford

S. Mukherjee $(\bowtie)$

Department of Earth Sciences, Indian Institute of Technology Bombay, Powai, Mumbai 400 076, Maharashtra, India

e-mail: soumyajitm@gmail.com

Received: 7 July 2011 / Accepted: 2 December 2011/Published online:

12 January 2012

(C) Springer-Verlag 2012 